\title{
TANGGUNG JAWAB HUKUM TERHADAP PEMBERI INFORMASI \\ PALSU YANG MENGANCAM KESELAMTAN PENERBANGAN BERDASARKAN UNDANG-UNDANG NOMOR 1 TAHUN 2009
}

\author{
LAILATUL UZNI \\ (Mahasiswa Program S1 Fakultas Hukum Universitas Tarumanagara) \\ (E-mail: lalilulelo1096@gmail.com)

\section{Dr. Amad Sudiro, S.H., M.H., M.M., M.Kn. \\ (Corresponding Author)} \\ (Dosen Fakultaas Hukum Universitaas Tarumanagaraa. Meraih Sarjana Hukum pada Fakultas Hukum \\ Universitas Trisakti Tahun 1990, Magister Hukum pada Fakultas Hukum Universitas Tarumanagara \\ Tahun 1997, Doktor (Dr.) pada Fakultas Hukum Universitas Indonesia Tahun 2011)
}

(E-mail: ahmads@fh.untar.ac.id)

\begin{abstract}
Air transportation is something that is currently very loved by almost every society, this is because air transportation has a fast, up-to-date and efficient mobilization, but transportation with this airplane mode if it is not accompanied by qualified safety rules will have a negative impact on every individual who uses it. hence from that society and government must be more wise in enforcing existing legal rules for the sake of creating security and safety in the flight itself, because flight is one of the safest transportation according to existing data, therefore in order to maintain the good name of air transportation, especially aviation, there is a need for compliance with any existing regulations that have been determined by the government, cannot be arbitrary. in flight it upholds the meaning of safety and security for every passenger and cabin crew, because it is the priority of every airline safety is the dead price for each mode of transportation. so that air transport modes, especially airlines, are getting better, then we need to work from ourselves in safeguarding every word and behavior that can endanger the safety and security of aviation.
\end{abstract}

Keywords : Aviation safety, according to the Act

\section{PENDAHULUAN}

\section{A. Latar Belakang}


Indonesia yang diberkahi menjadi daerah kepulauan dimana terbagi dalam ribuan puulau, terbagi mengitari daerah garis katulistiwa, yang dibagi menjadi 2 benuaa juga 2 samuddra, dengan tempat cukup besar. Karena sebab itu negara kita memiliki tempat sama peran yaitu cukup di pentingkan juga pas di lingkup internasionaal. guna meraih akhir perkembangan nasionaal jadi pengalamaan pancasilaa sama Undang-Undaang Daasar Negaara Repubblik Indoneesia Tahun 1945, mewujudkaan Wawasan Nuusantara dan juga mengukuhkan pertahanan kenasioanalan indonesia, di butuhkan system transportasih nasyional dan memiliki arti pentiing sama strategiis di perkembangan indonesia yang berwawaasan alam. ${ }^{1}$ Traansportasi uudara adalah mesin traansportasi yg mutahir dan terlincah, juga menjangkau cukup luaas kerana mempunyai beberapaa kebanyakan, diantaranya yaiitu adalah :

1. Faktor yang cepat, relatif lebih cepat dibandingkan dengan moda angkutan lain, oleh sebab di traansportasi uudara memilih peesawat penerbangan yg punya tingkat cepat.

Keberuntungan selanjutnya dari angkutaan oksigen yaitu bahwa jaasanya bias diberikan kepada mejangkau tempat-tempat terpencil yg susah dijangkau

2. oleh moda angkutan lain misalnya daerah-daerah yang tinggi seperti gunung dan bukit dapat dijangkau oleh transportasi darat.

3. Untuk angkutan yang jaraknya jauh angkutan udara lebih efisien dari segi waktu dan kuantitas dayaa angkut dapat membawa penumpang dan barang yang berjarak agak jauh dan banyak.

4. Timbulnya keteraturan jatwal juga frekwensi pada pesawat terbang. pengangkutan udaraa merupakan bagian dilakukan dengan cara pesawaat udaraa jadi membawa orang-orang, barang, barang serta poos kepada hal perjalanaan juga lebiih daari sebuah bandara ke bandara dan lain atau

${ }^{1)}$ K. Martono, Hukum Peneerbangan berdasaarkan UURI No.1 Tahuun 2009. Cetakan ke-1, (Bandung: CV. Mandar Maju, 2009), hal. 3. 
bebraapa bandara. ${ }^{2)}$ Moda ini adalah sebagai sebuah fasilitas guna membuat lancar preknomian, memberi aksess kepada tempat-tempat susah dijangkau bisa juga terpenciil, mengukuhkan pemersatuan bangsa indosnesia, menegakan kedaulataan negeri, dan juga mempeengaruhi seluruh sisi hidup bangsa. Bagian terpenting moda ini tercemin ada menjadi lebih menaikkan keberadaan jasaa pengangkutan oleh perpindahan oraang juga kargoo dindonesia,mulai juga keluarr negera, juga berperann sebagi pendoroong, juga menggerakan bagi pertumbuhan daerah dan penggerak daerah. Sadar akan guna tranasportasi itu, penyelenggaraaan penerbangann sesuai ditata dallam 1 penyatuan system moda nasional jadi terpandu dan dapat terwujudkan menyediakan jasaa transportasii yg sama oleh tinggi kebutuhann, selamatt, amaan, efektip dan efisyen. ${ }^{3)}$ moda ini ia memiliki sifat dan kebisaan sendiri, harus diperkembangkan supaya bisa peningkatan pelayanan bisa lebih banyak, bisa dalam negeri ataupun keluar negeri. Pekgembangan moda terbang disusun pada satu kesatuaan sistemm yang menghubungkan juga pedinamisasian pra saraana juga saranaa moda menerbangan, metode, prosedurisasi juga praturan menjadi daya pakai akan berhasiil juga. Sebagai Negara berkembang, Indonesia juga tidak mau kalah bersaing dengan negaranegara lainnya didunia dalam perkembangan teknologi transportasi, mulai dari transportasi laut, darat dan udara. Berbagai inovasi dibidang transportasi mulai diterapkan dikota-kota besar seperti ibu kota DKI Jakarta misalnya jalur busway, fly-over, sampai rencana pembangunan Mass Rapid Transporation (MRT) yang cukup kontroversial itu.

Pada intinya transportasi atau peng angkutana ialah pemindahan tempatt, bisa tentang benda- bbenda ataupun orang dan orang,oleh sebab perrpindahan itu absolut memerlukan guna menuju dan mentinggikan manfaatt dan

${ }^{2)}$ Sinta Ulii, Pengangkuutan Suatuu Tinjauan Hukkum Multimoida Transhport Angkutan Lautt, Angkutaan Daarat dan Angkutan Uudara, (Mednan: USuU Presss, 2006), haal. 200.

${ }^{3)}$ Ibid., hal. 4. 
efisyensi. ${ }^{4)}$ Peranan juga fungsi transportasi udara bagi Indonesia mempunyai posisi strategis ditinjau dari berbagai aspek. Transportasi ini adalah satusatunyaa jalan yg cepaat, efisyien seta ekonomiss terhadap mengangkutan dari pulauu juga antar kota, apalagi antaar tempat terpenciil pada pulau dan pulau lain di luarr Jawaa. ${ }^{5)}$ Di sisi lain transportasi uddara jga mrupaakan sarrana pentinng baagi penngembangan peerdagangan, ekonomi dan industry priwisata dii Indonesiia sebagaai negeri yg banyak akan budaya dan traadisi. ${ }^{6}$

\section{A. Kasus Candaan Bom dalam Pesawat Lion Air JIT-6087 di Baandara Supadiyo Pontianakk Tahun 2018}

Paada harii Seniin tgll 208 Mey 20181 skitar pukul 18.20 Wibb di Peswawat Lioon Aiir JIT-687 Bandaura Inteernasional Supadyo Pnntianak, Kalimantan Barat telah diamankan seorang penumpang pesawat Lion Air atas nama Frantinus Nirigi yang menyampaikan bahwa barang bawaannya tersebut adalah "Bom". Pada saat pesawat Final Gate. Nama lengkapnya pelaku tersebut sesuai dengan Kartu Mahasiswa adalah Frantinus Nirigi yang juga tercantum sbagai maahasiswa Uuniversitas Tanjung Pura, Fakultas Iilmu Sosiall dann Ilmuu Poolitik Program Sarjana S1 prodi Administrasi Negara.

Kejadian pada jam 18.20 Wib Pesawat Lion Air JIT-6807 dengan tujuan Pontyianak - Jaakarta sedang boarding. Di saat Frantinus Nirigi di dalam pesawat Lion Air JT-687 yang sedang memasukkan barang ke kabin dihampiri pramugari bernama Cyndi dengan maksud menanyakan barang bawaan. Farantinus Nirigi langsung menjawab ada "Bom". Mendengar teriakan ada Bom maka penumpang yang lainnya panik, dan tidak lama berselang seluruh penumpang berdesak-

4) Sutiion Uzman Addji, Huukum Peengangkutan Dii Inndonesia, Ceetakan ke-2, (Jakkarta: PT. Rinkaa Ciipta), hal.1q.

5) E. Wiradipradja, Saefullah Huukum Trannsportasi Uddara Darii Waarsawa 19299 keen Montreaal 10999, (Banduung: Peenerbit PT. Kblat Buku uUtama, 20008), hal. 18.

6) Ibid, hal. 18 . 
desakan untuk keluar dari Pesawat Lion Air JT 687 dan pramugari tidak bisa menenangkan penumpang dan ada seorang penumpang yang sangat panik membuka pintu darurat/emergency untuk keluar dari pesawat. Sekitar pukul 19.00 Wib Frantinus Nirigi diamankan di Airport Duty Officer Bandara Internasional Supadio untuk dilaksanakan pemeriksaan oleh Security Avsec dan pihak kepolisian terhadap barang bawaannya tersebut, setelah dilaksanakan pemeriksaan tidak ditemukan barang yang mengarah kepada Bom. Setelah 1,5 jam pemeriksaan Fransiskuus Niriigi dibawwa kee Poolresta Koota Ponntianak uuntuk dilaksanaakan prooses leebih lannjut. Sesuai jadwal penerbangan pesawat Lion Air JIT 6807 tujuan Jakartaa dari Bandaraa Internasyional Supadiyo, Pontiianak, berangkat pukul 18.50. Namun keberangkatan itu tertunda lantaran adaa pennumpang yg mengaku mbawa boom di taas. Situasi di pesawat itu tampak mencekam. Para penumpang berebut untuk keluar dari pesawat. Nampak adaa bannyak peenumpang yaang berrdiri dii saayap pesawaat ntuk kluar. Infoinya parra penummpang keetakutan kaarena anncaman bbom iitu keemudian adaa yg mmbuka piintu daruurat. Uusai piintu daruurat trbuka, pnumpang berhammburan kluar psawat.

Menurut penulis dalam hal ini tanggung jawab dikaitkan dengan sesuatu yang telah kita lakukan, lalu memiliki akibat atau hal yang memiliki dampak dan oleh karena itu di gantikan atau diperbaiki dengan cara yang disebut sebagai tanggung jawab, dan sesuaru yang diharuskan dan wajibkan atas dirinya untuk mengemban tanggung jawab tersebut. Transportasi Udara saat ini sudah sangat melekat dengan aktifitas masyrakat Indonesia. Sebagian masyarakat melakukan kegiatan bepergian, mobilisasi dari satu tempat ke tempat lainnya dengan jarak tempuh yang cukup jauh yang tidak dapat di jangkau 
dengan transportasi lainnya. Dan transportasi udara menjadi salah satu moda transportasi yang paling aman karena telah melewati serangkaian uji kelaikan terbang dan lain sebagainya, dengan transportasi udara seseorang dapat berpindah atau mobilisasi dari satu daerah atau pulau ke pulau lainnya, atau dari satu negara ke negara lain dengan jarak tempuh yang bervariasi dan waktu tempuh yang cepat dibandingkan moda transportasi lainnya.

Transportasi Udara khususnya Pesawat Terbang sebagai bagian yang tidak terpisahkan dengan sistem Transportasi nasional diselenggarakan berdasarkan asas kepentingan umum yang dimaksud adalah bahwa pengangkut harus lebih mengutamakan kepentingan masyarakat luas dari pada perseorangan atau kelompok dengan memperhatikan keselamatan, kenyamanan, dan ketertiban.

Penerbangan diselenggarakan dengan tujuan untuk mewujudkan penyelenggaraan penerbangan yang tertib, teratur, selamat, aman, nyaman dengan harga yang wajar, dan menghindari praktik persaingan usaha yang tidak sehat. Serta memperlancar arus perpindahan orang dan atau barang melalui udara dengan mengutamakan dan melindungi angkutan udara dalam rangka memperlancar perekonomian nasional. Membina jiwa kedirgantaraan, menjunjung kedaulatan negara, menciptakan daya saing dengan mengembangkan teknologidan industri angkutan udara nasional, menunjang, menggerakan, dan mendorong pencapaian tujuan pembangunan nasional, memperkukuh kesatuan dan persatuan bangsadalam rangka perwujudan wawasan nusantara, serta meningkatkan ketahanan nasional dan mempererat hubungan antar bangsa. ${ }^{7)}$ Beberapa contoh kasus lain mengenai Informasi Palsu dalam

\footnotetext{
7) Ibid. Pasal 3.
} 
hal Candaan Bom di dalam Penyelenggaraan Penerbangan sepanjang Tahun 2015, di antaranya :

1. Lion Air JT9973 Rute BTH-KNO (Batam Hang Nadim-Kuala Namu Medan) registrasi PK-LGM Tersangka "SMS" (4 MEI 2015);

2. Lion Air JT3079 Rute BTbH-KNO registrasi PK-LFkW tersangka "Srt" (7 Mei 2015);

3. Lion Air JT0330 Rute CcGK-PLM registrasi PK-LkGT tersangka "BP" (13 Mei 2015).

Dan yang terakhir terjadi di pertengahan Tahun 2018 mahasiswa Universitas Tanjungpura yaitu Frantinus Nirigi, warga Papua yang terjerat kasus informasi palsu mengenai bom di pesawat Lion aAir Ji0T 687 yang telah dii vonis 5 bulan 10 hari kurungan pidana penjara.

\section{B. Perumusan Masalah}

Berdaasarkan laatar beelakang uraiian di aatas, meelihat bettapa pentingnya perlindungan hukum bagi konsumen penerbangan terhadap permasalahanpermasalahan yang terjadi, penulis tertarik untuk melakukan penelitian lebih lanjut yang dituangkan dalamn skripsi dengan judul : "Tanggung Jawab Hukum Terhadap Pemberi Informasi Palsu yang Mengancam Keselamatan Penerbangan Berdasarkan Undang-Undang No. 1 Tahun 2009?"

\section{1) Tujuan dan Kegunaan Penelitian}

\section{a) Tujuan Penelitian;}

Tujuan dilakukan Penelitian ini bertujuan :

Mengetahui dan Mengkaji Bentuk Tanggung Jawab Hukum terhadap Pemberi Informasi Palsu yang mengancam Keselamatan Penerbangan dilihat dari perspeektif Undang-Undang No. 1 Tahun 2009 Tentang Penerbangan.

\section{b) Metode Penelitian}


Penelitian hukum adalah suatu proses untuk menemukan aturan hukum, prinsip-prinsip hukum, maupun doktrin-doktrin hukum guna menjawab isu hukum yang dihadapi. ${ }^{8)}$ Berdasarkan judul yang diangkat oleh Penulis, maka metode penelitian yang digunakan Penulis adalah sebagai berikut:

1. Tipe Penelitian

Tipe penelitian yang digunakan oleh Penulis adalah tipe penelitian Normatif. Alasan Penulis memilih metode ini dalam rangka mencari kebenaran koherensi adalah mendapatkan sesuatu yang secara aksiologis merupakan nilai atau ketetapan/aturan sebagai referensi untuk ditelaah. ${ }^{9}{ }^{9}$

2. Jenis dan Sumber Penelitian Hukum

Dalam penelitian ini, Penulis menggunakan jenis bahan hukum sekunder. Bahan hukum sekunder adalah bahan yang diperoleh dari telaah kepustakaan dan literatur, untuk memecahkan isu hukum dan sekaligus memberikan preskripsi mengenai apa yang seyogianya, diperlukan sumber-sumber penelitian. ${ }^{10)}$ Penelitian yang dilakukan berdasarkan bahan hukum sekunder di mana data ini berasal dari bahan-bahan sebagai berikut:

a. Bahan hukum primer, yaitu bahan-bahan hukum yang mengikat. Bahan hukum primer ini terdiri dari peraturan perundang-undangan, yaitu:

1) Undang-Undang Nomor 1 Tahun 2009 tentang Penerbangan

2) Peraturan Menteri Perhubungan No. 21 Tahun 2015 mengenai Standar Keselamatan Penerbangan

b. Bahan hukum sekunder, yaitu bahan-bahan yang memberikan penjelasan mengenai bahaan hukum primer dan dapat mmbantu menganalisa, memahami, dan menjelaskan bahan hukum primer, antara lain: teori atau pendapat para sarjana, hasil karya dari kalangan hukum, penelusuran

8) Peter Mahmud Marzuki, Penelitian Hukum Edisi Revisi, Cetakan ke-8. (Jakarta: Kencana Prenada Media Group, 2013), hal. 35.

${ }^{9)}$ Ibid, hal. 33.

${ }^{10)}$ Ibid, hal. 181. 
internet, artikel ilmiah, jurnal, majalah, surat kabar, makalah, dan sebagainya.

c. Bahan non hukum, yaitu bahan-bahan penunjang dari bahan hukum sekunder dan memberikan informasi tambahan bagi penelitian ini seperti Kamus Besar Bahasa Indonesia (KBBI) dan ensiklopedia serta petunjuk tambahan berupa wawancara dengan narasumber (ahli hukum).

\section{Pendekatan}

Dalam penelitian hukum terdapat beberapa macam pendekatan. Dengan pendekatan tersebut peneliti akan mendapatkan informasi dari berbagai aspek mengenai isu yang sedang dicoba untuk dicari jawabannya. Terdapat 5 (lima) macam pendekatan, yaitu: ${ }^{11)}$

1) Pendekatan Undang-Undaang (statute approach);

2) Pendekatan kasus (case approach);

3) Pendekatan historis (historical approach);

4) Pendekatan komparatif (comparative approach);

5) Pendekatan konseptual (conceptual approach).

Pada penelitian ini penulis memakai 1 (satu) macam pendekatan, yaitu pendekatan Undang-Undang (statute approach). Pendekatan undang-undang adalah pendekatan yang dilakukan dengan menelaah semua Undang-Undang maupun regulasi yang berkaitan dengan kasus yang dibahas.

Metode pendekatan ini dipilih karena dalam penelitian ini, Penulis melakukan telaah terhadap semua peraturan perundang-undangan dan doktrindoktrin yang terkait dengan Tanggung Jawab Penumpang atau Pengguna Jasa Transportasi Udara ini mampu menyesuaikan secara lebih mudah untuk berhadapan dengan kenyataan.

4. Teknik Pengumpulan Bahan Hukum

\footnotetext{
11) Ibid, hal. 93.
} 
Tehnik pengumpulan bahan hukum dimaksudkan untuk memperoleh bahan hukum dalam penelitian. Teknik pengumpulan bahan hukum yang mendukung dan berkaitan dengan pemaparan penelitian ini adalah studi dokumen (studi kepustakaan). ${ }^{12)}$

5. Teknik Pengelolaan Bahan Hukum

Teknik pengolahan bahan hukum yang digunakan Penulis adalah pengolahan yang secara runtut dan sistematis sehingga memudahkan penulis melakukan analisis. Pengelolaan bahan hukum dilakukan secara sistematis bertujuan untuk mendapatkan gambaran umum dari hasil penelitian.

6. Teknik Analisis Bahan Hukum

Teknik analisis bahan hukum yang Penulis gunakan dalam penelitian ini adalah dengan menggunakan metode analisis bahan hukum kualitatif, yaitu tata cara penelitian yang menghasilkan data deskriptif analitis dari apa yang diperoleh secara tertulis, agar data-data itu dapat diteliti dan dipelajari untuk menganalisis obyek penelitian yang utuh secara mendalam dan komprehensif, sehingga pada akhirnya dapat mengerti serta memahami aspel-aspeek yang menjadi obyek penelitian. ${ }^{13)}$

\section{PEMBAHASAN}

\section{Pengertian Pengangkutan Udara}

Pada dasarnya, masyarakat mendefinisikan kata pengangkutan seriing diganti dengan ucapan transportasi. Dalam Undang-undaang Nomor 1 Tahun 2009 tentang Penerbangan (setelah itu disingkat Undang-undang Penerbangan) banyak ditemukan penggunaaan kata pengangkutan dan transportasi. pengangkutan lebih menekankan oleh aspek kegiatan

\footnotetext{
12) Ibid, hal. 21.

${ }^{13)}$ Ibid, hal. 109 .
} 
perekonomian, akan tetapi keduanya memiliki makna yang sama, yaitu sebagai kegiatan pemindahan dengan menggunakan alat angkut. ${ }^{14)}$

1. Prisnsip Praduga bahwa pengangkut selalu bertanggung jawab (presumtion of liability)

Prinsip ini merupakan prinsip "parduga bahwa pengangkut selalu bertanggung jawab", tanpa ada keharusan bagi pihak yang dirugikan untuk membuktikan bahwa ada perbuatan melawan hukum dari pengangkut. Prinsip berdasarkan pada perjanjian pengankutan, akan tetapi pengangkut dapat membebaskan diri dari tanggung jawabnya, apabila pengangkut dapat membuktikan bahwa:

a. Kerugian yang disebabkan oleh kecelakaan yang selayaknya tidak dapat dicegah atau dihindari ataru berada diluar kekuasaannya;

b. Ia telah mengambil semua tindakan yang dperlukan untuk menghindarkan timbulnya kerugian;

c. Kerugian yang timbul bukan karena kesalahannya, dan

d. Kerugian ditimbulkan oleh kelalaian atau kesalahan dari penumoang sendiri karena cacat, sifat atau mutu barang yang diangkut.

2. Prinsip tanggung jawab mutlak (strict liability)

Prinsip ini mengandung pengertian, pengangkut harus bertanggung jawab tanpa melihat ada atau tidak adanya kesalahan atau tidak melihat siapa yang bersalah, atau suatu prinsip tanggung jawab yang memandang kesalahan sebagai suaru yang tidak relevan untuk dipermasalahan apakah pada kenyataannya ada atau tidak ada. ${ }^{15)}$

2. Prinsip pembatasan tanggung jawab (limitation of liability)

14) Ahmad Zazili, "Perlindungan Hukum Terhadap Penumpang Pada Transportasi Udara Niaga Berjadwal Nasional”, Thesis,(Semarang, Universitas Diponegoro, 2008), hal. 28.

${ }^{15)}$ Ibid., hal. 25-26. 
Prinsip pembatasan tanggung jawab ini ada yang bersifat breakable limit dan unbreakable limit. Breakable limit, artinya dapat dilampaui dan bersifat mutlak, dimana ganti rugi yang diberikan oleh pengangkut masih dapat diterobos, atau ganti rugi yang dibayarkan masih boleh melebihi jumlah yang dibayarkan masih boleh melebihi jumlah yang dinyatakan, yaitu dalam hal kerugian disebabkan oleh adanya perbuatan sengaja (willful misconduct) dari pengangkut. Hal ini berarti tanggung jawab pengangkut dan ganti rugi yang harus dibayarkan tidak boleh melebihi jumlah yang dinyatakan. ${ }^{16)}$

\section{Pengertian Tanggung Jawab}

Pengeertian tanggung jawab secara umum sangat luas. Peter Salim membagi tanggung jawab responsibility menjadi tiga kelompok besar yaitu : ${ }^{17)}$ Tanggung jawab dalam arti accountability

Tanggung jawab dalam arti accountability biasanya berkaitan dengan keuangan atau prmbukuan. Accountability dapat pula diartikan sesuatu yang bersinambungan dengan pembayaran. ${ }^{18)}$

Tanggung jawab dalam arti responsibility

Tanggung jawab dalam arti responsibility dapat diartikan "ikut memikul beban" akibat suatu perbuatan. Tanggung jawab juga dapat diartikan "kewajiban memperbaiki" kembali kesalahan yang pernah terjadi. Tanggung jawab dalam arti responsibility juga dapat berarti wajib menanggung segala sesuatu, jika terjadi apa-apa yang dapat disalahakan, dituntut dan di ancam hukuman pidana oleh penegak hukum di depan pengadilan, menerima beban akibat tindakan sendiri atau orang lain.

1. Tanggung jawab dalam arti liability

\footnotetext{
16) Ibid., hal. 28-29.
}

17) Ibid, hal, 213. 
Selain dalam arti accountability, responsibility, tanggung jawab juga berarti liability. Tanggung jawab liability dapat pula berarti menanggung segala sesuatu kerugian yang terjadii akibat perbuatannya atau perbuatan orang lain yang bertindak untuk dan atas namanya. Tanggung jawab liability dapat juga diartyiakn kewajiban membayar kerugianyang diderita, misalnya dalam perjanjian transportasi udara, perusahaan penerbangan "bertanggung jawab" atas keselamatan penumpang dan/atau barang kiriman. ${ }^{19)}$

2. Tanggung Jawab Hukum Berdasarkan Kesalahan

Tanggung jawab hukum atas dasar kesalahan ( based on fault liability) terdapat dalam Pasal 1365 KUH Perdata. Pasal tersebut yang dikenal sebagai tindakan melawan hukum berlaku umum terhadap siapapun. Menurut pasal tersebut setiap perbuatan melawan yang menimbulkan kerugian terhadap orang lain mewajibkan orang yg karena perbuatannya menimbulkan kerugian itu mengganti kerugian. ${ }^{20)}$

Menurut Pasal 1367 KUH Perdata tanggung jawab hukum kepada orang yang menderita kerugian tak hanaya terbatas kepada perbuatan sendiri, melainkan juga perbuatan karyawan, agen, pegawai, perwakilannya apabila menimbulkan kerugian kepaada orang lain, sepanjang orang tersebut bertindak sesuai dengan tugas dan kewajiban yang dibebankan kepada orang tersebut. Pada konsepnta tanggung jawab atas dasar kesalahan berlaku (based on fault liability) terhadap semua perusahaan angkutan. Tanggung jawab atas dasar ksalahan (based on fault liability) harus memenuhi unsur-unsur ada keslahan, ada kerugian, yang membuktikan adalah korban yang menderita kerugian, keududukan tergugat dengan penggugat sama tinggi dalam arti saling membuktikan, bilama terbukti ada kesalahan maka jumlah ganti kerugiian tidak terbatas (unlimited liability). ${ }^{21)}$

\footnotetext{
19) Ibid, hal. 217.

20) ibid, hal. 219.

${ }^{21)}$ Ibid, hal. 220.
} 
Tanggung jawab berdasarkan kesalahan harus ada unsur berupa kerugian maupun kesalahan. Kerugian tersebut harus ada hubungannya dengan kesalahan, ada kerugian tetapi tidak ada kesalahan, maka perusahaan penerbangan tidak bertanggung jawab, demikian pula ada kesalahan tetapi tidak menimbulkan kerugian, maka perusahaan penerbangan tidak bertanggungjawab. ${ }^{22)}$

Candaan bom bukanlah sesuatu yang dapat dianggap remeh, hampir setiap orang jika mendengar istilah mengenai bom akan langsung berfikir itu adalah sesuatu yang dapat mengancam keselamatan serta keamanan, candaan mengenai bom sangatlah sensitif bagi setiap orang yang mendengarnya, belum lagi jika mereka yang memiliki trauma dengan kata "bom", jika di telaah kembali apakah keuntungan dari sebuah lelucon mengenai bom, menurut penulis kata-kata mengenai bom atau candaan tentang bom itu bukan lagi suatu hal yang bisa kita ucapkan di sembarang tempat, apalagi akhir-akhir ini di pemberitaan seringkali muncul berita mengenai bom, teroris, bom bunuh diri dan lain sebagainya, oleh karena itu banyak orang yang berfikir bahwa bom adalah suatu hal yang bgitu ditakuti banyak orang dan menjadi sebuah ancaman bagi jiwa mereka, tempat-tempat umum seperti bandara, stasiun, rumah sakit, pusat perbelanjaan, tempat ibadah dan lainnya merupakan tempat yang ramai yang seharusnya tidak diperkenankan setiap orang mengucapkan hal-hal yang mengandung unsur ancaman seperti bom. Dan kesimpulan dari yang telah di uraikan diatas penulis mencoba mengamati bagaimana penegakkan hukum bagi pelaku pemberi informasi palsu khususnya mengenai bom yang harus diberlakukan setegas-tegasnya, karena penulis banyak sekali mendapati banyak kasus dari artikel-artikel resmi media massa yang memberitakan mengenai candaan bom yang mana pelaku jarang di kenakan hukuman yang telah ditentukan oleh Undang-undang yang

22) H.K. Martono dan Agus Pramono, Hukum Udara Perdata Internasional dan Nasional, Catatan ke-1, (Jakarta: Raja Grafindo Persada, 2013), hal. 11. 
berlaku, hanya sekedar dimintai keterangan oleh pihak bandar udara dan perkara selesai sampai disitu dengan penyelesaian dengan cara permintaan maaf dari pihak terkait, seharusnya pelaku tersebut wajib di tindak lanjuti dan di proses hukum sesuai dengan peraturan yang ada, karena jika hal seperti ini terus terjadi, setiap pelaku penyebaran informasi palsu hanya diloloskan begitu saja tanpa adanya proses hukum maka akan terus kembali terjadi karena tidak ada efek jera bagi pelaku untuk melakukan hal-hal tersebut dikemudian hari. Undang-undang dibuat untuk di menegakkan hukum yang ada, untuk meminimalisir terjadinya hal-hal yang bertentangan dengan peraturan tersebut, maka dari itu masyarakat serta pemerintah haruslah bijak dan mau bekerja sama dalam penegakan hukum yang ada. Transportasi Udara saat ini sudah sangat melekat dengan aktifitas masyrakat Indonesia. Sebagian masyarakat melakukan kegiatan bepergian, mobilisasi dari satu tempat ke tempat lainnya dengan jarak tempuh yang cukup jauh yang tidak dapat di jangkau dengan transportasi lainnya. Dan transportasi udara menjadi salah satu moda transportasi yang paling aman karena telah melewati serangkaian uji kelaikan terbang dan lain sebagainya, dengan transportasi udara seseorang dapat berpindah atau mobilisasi dari satu daerah atau pulau ke pulau lainnya, atau dari satu negara ke negara lain dengan jarak tempuh yang bervariasi dan waktu tempuh yang cepat dibandingkan moda transportasi lainnya.

Transportasi Udara khususnya Pesawat Terbang sebagai bagian yang tidak terpisahkan dengan sistem Transportasi nasional diselenggarakan berdasarkan asas kepentingan umum yang dimaksud adalah bahwa pengangkut harus lebih mengutamakan kepentingan masyarakat luas dari pada perseorangan atau kelompok dengan memperhatikan keselamatan, kenyamanan, dan ketertiban.

Peran serta fungsi transportasi udara bagi Indonesia memiliki posisi yang sangat strategis ditinjau dalam berbagai aspek. Transportasi udara adalah satu-satunya alternatif yang cepat dan mudah serta efisien juga 
ekonomis bagi pengangkutan antar pulau dan serta antar daerah, terutama antar daerah terpencil di pulau-pulau besar diluar Jawa.

Penanggulangan tindakan melawan hukum diatur dalam Pasal 344 Undang-undang Nomor 1 Tahun 2009 tentang penerbangan, terkait penyampaian informasi palsu yg membahayakan keselamatan penerbangan diatur dalam huruf e, dan untuk ketentuan pidana nya diatur dalam pasal 437 Undang-undang nomor 1 Tahun 2009 tentang Penerbangan.

Menerapkan ancaman pidana yang tertuang dalam pasal 437 Undangundang Nomor 1 Tahun 2009 mengenai Penerbangan. Di dalam beberapa kasus sudah di terdapat putusan pengadilan, contoh kasus candaan membawa bom di pontianak, hal ini merupakan informasi palsu yangb dapat membahayakan keselamatan penerbangan serta membuat keamanan dan kenyaman menjadi terganggu.

Dan mengenai Pengampuan atau curatele merupakan suatu keadaan dimana seseorang yang sudah dewasa akan tetapi karena keadaan mental dan fisiknya dianggap tidak atau kurang sempurna sehingga diberikan kedudukan yang sama dgn seorang anak yang belum dewasa. Bagaimana apakah bisa dipertanggung jawabkan secara pidana penerbangan? Ini sama hal nya di pidana umum bisa atau tidak nya seseorang dipidana apabila dalam pengampuandan untuk penetapan seseorang perlu dalam pengampuan atau tidak harus dilakukan pemeriksaan terlebih dahulu, pemeriksaan kesehatan jiwa untuk kepentingan penegakan hukum perkara pidana bertujuan untuk menilai unsur-unsur :

a. Kemampuan dalam mempertanggungjawabkan tindak pidana yg telah dilakukan

b. Kecakapan mental untuk menjalani proses peradilan pidana 
Pelaku yang menyebabkan peristiwa tersebut harus ditindaklanjuti sesuai dengan peraturan perundang-undangan, dan apabila ada indikasi tindak pidana penerbangan akan ditindaklanjuti oleh tim penyidik PPNS atau (penyidik pegawai negeri sipil) di lingkungan Direktorat Jenderal Perhubungan, yang hasilnya akan diteruskan ke penyidik polisi untuk diteruskan ke kejaksaan dan ke pengadilan.

Salah satu bidang kehidupan yang selalu diupayakan menjadi lebih baik adalah sektor transportasi. Manusia membutuhkan transportasi yang aman, cepat dan teratur dalam menunjang mobalitas kehidupannya, baik dalam transportasi lokal, nasional maupun internasional.

Penerbangan diselenggarakan dengan tujuan untuk mewujudkan penyelenggaraan penerbangan yang tertib, teratur, selamat, aman, nyaman dengan harga yang wajar, dan menghindari praktik persaingan usaha yang tidak sehat. Serta memperlancar arus perpindahan orang dan atau barang melalui udara dengan mengutamakan dan melindungi angkutan udara dalam rangka memperlancar perekonomian nasional. Membina jiwa kedirgantaraan, menjunjung kedaulatan negara, menciptakan daya saing dengan mengembangkan teknologidan industri angkutan udara nasional, menunjang, menggerakan, dan mendorong pencapaian tujuan pembangunan nasional, memperkukuh kesatuan dan persatuan bangsadalam rangka perwujudan wawasan nusantara, serta meningkatkan ketahanan nasional dan mempererat hubungan antar bangsa bangsa. Banyak keuntungan yang didapat dalam menggunakan moda transportasi ini, dengan jarak yang cukup jauh dapat ditempuh dengan waktu yang cukup singkat, jadi sangat berguna bagi masyarakat yang hendak bepergian jauh dan terencana dengan menggunakan moda transportasi udara khususnya pesawat terbang. Tetapi dalam hal ini banyak pula faktor yang menjadikan penerbangan menjadi sebuah hal yang agak ditakuti oleh sebagian masyarakat indonesia yang mana tidak dapat di tebak kerananya haruslah ada penegakkan hukum, yang mana mereka masih takut akan keamanan pesawat tersebut sebagai contoh masih takut menaiki pesawat karena takut akan ketinggian, ada pula yang 
tidak ingin naik pesawat dengan alasan harga tiket yang cukup mahal, dan masih banyak faktor lainnya yang membuat masyarakat takut untuk menggunakan transportasi ini. Selain itu transportasi udara juga merupakan sarana penting bagi pengembangan perdagangan, ekonomi dan industri pariwisata di Indonesia sebagai negara yang kaya akan budaya juga tradisi. Pentingnya transportasi udara tercermin pada semakin meningkatnya kebutuhan jasa angkutan udara bagi mobilitas orang serta barang di dalam negeri, dari dan ke luar negeri serta berperan sebagai pendorong dan penggerak bagi pertumbuhan daerah dan pengembangan wilayah. Pengangkutan udara, baik internasional maupun domestik mempunyai peranan dan fungsi yang makin penting dalam kehidupan umat manusia. Sukar dibayangkan dalam kehidupan modern dewasa ini tanpa adanya jasa pengangkutan udara.

Namun kegiatan yang seyogyanya dapat menjadi hal yang saling menguntungkan antara penumpang sebagai pengguna jasa penerbangan dengan maskapai penerbangan sebagai penyedia jasa penerbangan dapat menjadi suatu momok yang menakutkan dimana tidak jarang kegiatan penerbangan ini menjadi suatu bencana seperti kecelakaan pesawat udara, sabotase, terorisme, dan lain-lain. Kecelakaan penerbangan adalah hal yang sering terjadi di dalam kegiatan penerbangan, dimana salah satu factor penyebabnya adalah kesalahan manusia.

Terlebih dengan menguaknya kasus-kasus yang akhir-akhir ini membuat geger banyak masyarakat Indonesia mengenai penerbangan, sebagai contoh pada bulan Oktober 2018 lalu mengenai maskapai Lion Air PK-LQP dengan nomor penerbangan JT-610 yang mengalami lost contact dan hilang di Tanjung Karawang yang mana akan bertolak ke Bandar udara Depati Amir Pangkal Pinang. Selain itu adapula kasus mengenai harga tiket pesawat domestik yang melonjak tinggi, masyarakat dihebohkan dengan harga tiket yang melambung tinggi menjelang Lebaran tahun ini. Beberapa waktu lalu bahkan ramai diperbincangkan harga tiket rute Bandung-Medan seharga Rp 21 juta untuk kelas bisnis. Mahalnya tiket pesawat disebut-sebut disebabkan oleh kurangnya daya kompetisi penerbangan domestik. Dan faktor-faktor tersebut yang membuat banyak masyarakat memilih beralih dari menggunakan moda 
Transportasi udara khususnya pesawat terbang menajdi menurun, oleh karenanya pemerintah harus kebih memerhatikan kembali dan membenahi setiap hal-hal yang krusial yang berkaitan dengan moda transportasi ini. Oleh dari itu penulis menyinggung hal-hal yang berkaitan dengan keselamatan serta keamanan didalam penerbangan, karena hal ini menjadi inti dan bagian terpenting di dalamnya. kegiatan yang seharusnya dapat menjadi hal yang saling menguntungkan antara penumpang sebagai pengguna jasa penerbangan dengan maskapai penerbangan sebagai penyedia jasa penerbangan dapat menjadi suatu hal yang menakutkan dimana tidak jarang kegiatan penerbangan ini menjadi suatu bencana seperti kecelakaan pesawat udara, sabotase, terorisme, dan lain-lain. Kecelakaan penerbangan adalah hal yang terjadi di dalam kegiatan penerbangan, dimana salah satu faktor penyebabnya adalah kesalahan manusia atau (human error). Semakin berkembangnya penyelenggaraan angkutan udara dalam negeri maupun internasional, maka makin dirasakan keperluan adanya pengembangan peraturan-peraturan hukum yang mengatur hubungan-hubungan kepentingan dalam penyelenggaraan angkutan udara. Dalam praktek pengangkutan udara dewasa ini yang digunakan adalah peraturan-peraturan yang sudah ada, baik dalam bentuk undang-undang maupun peraturan-peraturan pemerintah lainnya serta peraturan internasional. Dan mengapa Penulis menyinggung mengenai Informasi Palsu khususnya candaan bom di dalam penerbangan karena banyak kasus yang terjadi dewasa ini, berawal sejak tahun 2015 hingga 2017, terdapat 54 candaan bom di bandara yang mengakibatkan penundaan keberangkatan pesawat. Dalam catatan detik.com sedikitnya ada 14 candaan soal bom mulai dari tanggal 1 hingga 28 Januari 2016. Itu artinya tiap dua hari sekali ada kejadian orang bercanda 'tak lucu' di kawasan bandara di Indonesia. Dan puncaknya terjadi pada mei 2018 terjadi hampir 15 kasus mengenai candaan bom dalam penerbangan, diakhiri dengan kasus Frantinus Nirigi seorang mahasiswa dari Universitas Tanjungpura yang mengatakan bom pada barang bawaannya kepada awak kabin dan petugas maskapai langsung menyerahkan Frantinus ke petugas operasional bandara untuk di ditindaklanjuti dan di proses sebagaimana mestinya. Pada hari Senin tanggal 28 Mei 2018 sekitar pukul 18.20 Wib 
di Pesawat Lion Air JT-687 Bandara Internasional Supadio Pontianak, Kalimantan Barat telah diamankan seorang penumpang pesawat Lion Air atas nama Frantinus Nirigi yang menyampaikan bahwa barang bawaannya tersebut adalah "Bom". Pada saat pesawat Final Gate. Nama lengkapnya pelaku tersebut sesuai dengan Kartu Mahasiswa adalah Frantinus Nirigi yang juga tercantum sebagai mahasiswa Universitas Tanjung Pura, Fakultas Ilmu Sosial dan Ilmu Plitik Program Sarjana S1 prodi Administrasi Negara. Kejadian pada jam 18.20 Wib Pesawat Lion Air JT-687 dengan tujuan Pontianak - Jakarta sedang boarding. Pada saat Frantinus Nirigi di dalam pesawat Lion Air JT-687 yang sedang memasukkan barang ke kabin dihampiri pramugari bernama Cyndi dengan maksud menanyakan barang bawaan. Farantinus Nirigi langsung menjawab ada"Bom". Mendengar teriakan ada Bom maka penumpang yang lainnya panik, dan tidak lama berselang seluruh penumpang berdesak-desakan untuk keluar dari Pesawat Lion Air JT 687 dan pramugari tidak bisa menenangkan penumpang dan ada seorang penumpang yang sangat panik membuka pintu darurat/emergency untuk keluar dari pesawat. Sekitar pukul 19.00 Wib Frantinus Nirigi diamankan di Airport Duty Officer Bandara Internasional Supadio untuk dilaksanakan pemeriksaan oleh Security Avsec dan pihak kepolisian terhadap barang bawaannya tersebut, setelah dilaksanakan pemeriksaan tidak ditemukan barang yang mengarah kepada Bom. Setelah 1,5 jam pemeriksaan Fransiskus Nirigi dibawa ke Polresta Kota Pontianak untuk dilaksanakan proses lebih lanjut. Sesuai jadwal penerbangan pesawat Lion Air JT 687 tujuan Jakarta dari Bandara Internasional Supadio, Pontianak, berangkat pukul 18.50. Namun keberangkatan itu tertunda lantaran ada penumpang yang mengaku bawa bom di tas. Situasi di pesawat itu tampak mencekam. Para penumpang berebut untuk keluar dari pesawat. Nampak ada banyak penumpang yang berdiri di sayap pesawat untuk keluar. Informasinya para penumpang ketakutan karena ancaman bom itu kemudian ada yang membuka pintu darurat. Usai pintu darurat terbuka, penumpang berhamburan keluar pesawat. Korban yang dirawat ke rumah sakit sekitar 7 orang dengan nama : $\begin{array}{lllll}\text { 1. Fikri } & \text { seat } & 18 & \text { D. }\end{array}$ 
2.

3.

4.

5.

6.

7.
Musanip

Suwarni

Hin

Purnama

Rusli

Iyan seat

seat

Djap

Sari

seat

Wijaya
27

21

21

26

seat
28

E.

A.

B.

E

F.

19

D.

Korban yang tidak dirawat dan sudah diperbolehkan pulang dari rumah sakit ada beberapa orang dengan nama Dadang seat 15 E, Anak dari Slamet an. Ferdi seat $32 \mathrm{C}$ dan seat 32 A, Bao Yi seat 24 E sedangkan yang membuka pintu darurat/emergency gate Alqadri Jafar seat 17 D. Dengan perbuatan yang seperti tersebut mengakibatkan banyak jadwal penerbangan yang terganggu. Sekarang ini Bandara Internasional Supadio berjalan lancar dan aman. Manager Operasional PT AP II Bandara Internasional Supadio Kubu Raya, Pontianak, Kalimantan Barat, Bernard Munthe menyatakan, isu bom di bandara merupakan candaan dari penumpang. Bernard menerangkan, pada pukul 18.40 WIB, petugas Avsec menerima laporan bahwa ada ancaman bom dari salah satu penumpang pesawat Lion Air nomor penerbangan JT 687 tujuan Pontianak-Jakarta. Penumpang tersebut atas nama Frantinus Sigiri, mahasiswa salah satu perguruan tinggi di Pontianak. "Yang bersangkutan ini, ketika tasnya akan diperiksa pramugari, mungkin barang kali tidak senang dengan penempatan bagasi itu, mungkin keluar kata-kata bom," kata Bernard Munthe, Senin (28/5/2018). Itu pun, lanjut Bernard, sesuai keterangan Sigiri dan penumpang lainnya. Pihaknya masih melakukan klarifikasi. "Saat mendengar ada ancaman bom, pramugari melakukan melakukan briefing untuk melaporkan ke kapten, dan kapten memberikan pengumuman dalam pesawat," jelas Bernard. Setelah adanya pengumuman itu, pramugari menyampaikan ke semua penumpang untuk keluar perlahan-lahan. "Karena ada kata-kata ancaman itu, mungkin penumpang pada panik," katanya. Sementara ini, Sigiri sudah diamankan ke Polresta Pontianak. "Untuk dilakukan, investigasi selanjutnya. Tadi kita juga bersama TNI dan Polri 
sudah mengamankan penumpang yang bercanda itu," pungkasnya. Entah apa yang ada di benak orang-orang yang bercanda soal bom saat berada di kawasan bandara dan sekitarnya. Mayoritas dari mereka melakukan candaan itu ketika pemeriksaan barang-barang sebelum check in dan boarding. Oleh karena itu candaan membawa bom di pesawat dapat merugikan banyak pihak baik penumpang maupun pihak maskapai serta pihak pengelola bandar udara, karena hal yang berkaitan dengan bom ini sangatlah sensitif bagi setiap orang yang mendengarnya, kita tidak pernah tau apakan orang yang mendengarkan hal tersebut akan baik-baik saja atau ia memiliki suatu riwayat penyakit atau trauma yang bisa menyebabkan orang tersebut ternggangu kesehatan mental, jiwa serta psikisnya, oleh karenanya informasi palsu mengenai bom bukanlah suatu hal patut untuk dijadikan bahan becandaan. Dengan adanya candaan bom ini bisa berdampak pada delay atau terlambatnya waktu keberangkatan pesawat yang sudah ditentukan jadwalnya. Dan juga membuat kinerja beberapa kru bandar udara menjadi terhambat, belum lagi beberapa technical support yang terhambat, bahkan jika sudah mengundang petugas yang berwenang dan lain sebagainya. Akibat atau dampak yang di timbulkan dari adanya pemberian informasi palsu mengenai bom ini sangatlah merugikan banyak pihak. Menurut penulis kasus ini sangat menarik untuk diangkat karena kasus informasi palsu mengenai bom inikerap terjadi di Indonesia khususnya dalam dunia penerbangan, yang mana sudah jelas diatur dalam Pasal 344 huruf e jo Pasal 437 Undang-undang Nomor 1 Tahun 2009 mengenai Penerbangan yang mana Pasal tersebut menurut analisa Penulis tak kunjung di terapkan oleh pihak yang berwenang kepada pelaku, yang sudah jelas dalam Pasal tersebut menenrangkan sanksi dengan ancaman pidana penjara paling lama 1 (satu) tahun. Apabila mengakibatkan kecelakaan atau kerugian harta benda menjadi paling lama 8 (delapan) tahun, dan apabila mengakibatkan matinya orang, menjadi paling lama 15 (lima belas) tahun. Candaan bom bukanlah sesuatu yang dapat dianggap remeh, hampir setiap orang jika mendengar istilah mengenai bom akan langsung berfikir itu adalah sesuatu yang dapat mengancam keselamatan serta keamanan, candaan mengenai bom sangatlah sensitif bagi setiap orang yang 
mendengarnya, belum lagi jika mereka yang memiliki trauma dengan kata "bom", jika di telaah kembali apakah keuntungan dari sebuah lelucon mengenai bom, menurut penulis kata-kata mengenai bom atau candaan tentang bom itu bukan lagi suatu hal yang bisa kita ucapkan di sembarang tempat, apalagi akhir-akhir ini di pemberitaan seringkali muncul berita mengenai bom, teroris, bom bunuh diri dan lain sebagainya, oleh karena itu banyak orang yang berfikir bahwa bom adalah suatu hal yang bgitu ditakuti banyak orang dan menjadi sebuah ancaman bagi jiwa mereka, tempat-tempat umum seperti bandara, stasiun, rumah sakit, pusat perbelanjaan, tempat ibadah dan lainnya merupakan tempat yang ramai yang seharusnya tidak diperkenankan setiap orang mengucapkan hal-hal yang mengandung unsur ancaman seperti bom. Dan kesimpulan dari yang telah di uraikan diatas penulis mencoba mengamati bagaimana penegakkan hukum bagi pelaku pemberi informasi palsu khususnya mengenai bom yang harus diberlakukan setegas-tegasnya, karena penulis banyak sekali mendapati banyak kasus dari artikel-artikel resmi media massa yang memberitakan mengenai candaan bom yang mana pelaku jarang di kenakan hukuman yang telah ditentukan oleh Undang-undang yang berlaku, hanya sekedar dimintai keterangan oleh pihak bandar udara dan perkara selesai sampai disitu dengan penyelesaian dengan cara permintaan maaf dari pihak terkait, seharusnya pelaku tersebut wajib di tindak lanjuti dan di proses hukum sesuai dengan peraturan yang ada, karena jika hal seperti ini terus terjadi, setiap pelaku penyebaran informasi palsu hanya diloloskan begitu saja tanpa adanya proses hukum maka akan terus kembali terjadi karena tidak ada efek jera bagi pelaku untuk melakukan hal-hal tersebut dikemudian hari. Undang-undang dibuat untuk di menegakkan hukum yang ada, untuk meminimalisir terjadinya hal-hal yang bertentangan dengan peraturan tersebut, maka dari itu masyarakat serta pemerintah haruslah bijak dan mau bekerja sama dalam penegakan hukum yang ada.

\section{PENUTUP}

\section{A. Kesimpulan}


Tujuan utama dari kegiatan penerbangan adalah keselamatan penerbangan. Dalam hal keselamatan penerbangan tersebut diperlukan berbagai aspek hukum untuk mengaturnya, aspek hukum ini berkaitan erat dengan perlindungan konsumen terhadap pengguna jasa transportasi udara niaga, dalam konteks ini maka semua perusahaan penerbangan wajib untuk meminimalisir dan mengantisipasi segala kemungkinan yang dapat mencelakakan penumpangnya, oleh sebab itu setiap perusahaan penerbangan komersil dituntut untuk menyediakan armada pesawatnya yang handal dan selalu dalam keadaan layak terbang. Dan oleh karena keselamatan dalam penerbangan itu sendiri menjadi suatu hal yang sangat di haruskan maka dari itu penulis menyinggung mengenai pasal 437 Undang-undang Nomor 1 Tahun 2009 tentang Penerbangan karena beberapa kasus yang telah terjadi dewasa ini, pasal tersebut berbunyi sebagai berikut: "(1) Setiap orang menyampaikan informasi palsu yang membahayakan keselamatan penerbangan sebagaimana dimaksud dalam Pasal 344 huruf e dipidana dengan pidana penjara paling lama 1 (satu) tahun. (2) Dalam hal tindak pidana sebagaimana dimaksud pada ayat 1 mengakibatkan kecelakaan atau kerugian harta benda, dipidana dengan pidana penjara paling lama 8 (delapan) tahun. (3) Dalam hal tindak pidana sebagaimana dimaksud pada ayat (1) mengakibatkan matinya orang, dipidana dengan pidana penjara paling lama 15 (lima belas) tahun". Penerapan pasal tersebut merupakan rangkaian pemerintah dalam menjunjung tinggi arti kemana dan keselamatan di dalam penerbangan, karena akhir-akhir tahun ini sudah banyak merebak kasus mengenai Informasi Palsu di dalam Penerbangan yang pelakunya tidak jarang diloloskan begitu saja dengan hanya dimintai keterangan dan dibarengi dengan permintaan maaf darri pelaku dan dinilai masalah tersebut selesai, lalu adanya Undang-udang lalu dinilai untuk apa jika tidak untuk terapkan kepada Pelaku, maka dari itu inti dari Penulis mengangkat kasus ini adalah dimana kasus Informasi Palsu ini sering anggap remeh oleh sebagian orang terlebih 
konteksnya pada lelucon atau candaan bom. Dalam hasil wawancara Penulis kepada Narasumber terkait, beliau mengatakan bahwa guyonan atau candaan bom ini bukan lagi disebut lagi sebagai candaan tetapi dalam hal ini sudah memasuki kategori sebuah ancaman atau gretakan, hal ini tidak dapat dikatakan sebagai sebuah candaan, dan dalam konteks bom ini bukan lagi sebuah lelucon tapi sudah memasuki hal yang dianggap serius.

\section{B. Saran}

Jika hal seperti ini terus terjadi, setiap pelaku penyebaran informasi palsu hanya diloloskan begitu saja tanpa adanya proses hukum maka akan terus kembali terjadi karena tidak ada efek jera bagi pelaku untuk melakukan hal-hal tersebut dikemudian hari. Undang-undang dibuat untuk di menegakkan hukum yang ada, untuk meminimalisir terjadinya hal-hal yang bertentangan dengan peraturan tersebut, maka dari itu masyarakat serta pemerintah haruslah bijak dan mau bekerja sama dalam penegakan hukum yang ada.

\section{E. DAFTAR PUSTAKA}

\section{Buku}

Abdulkadir, Muhammad. Hukum Perusahaan Indonesia. (Bandung: Citra Aditya Bakti, 2010).

Sitompul, Asril. Hukum Internet mengenai masalah hukum di cyberspace, (Bandung: PT. Citra Aditya Bakti, 2004).

Nasution, Az. Hukum Perlindungan Konsumen Suatu Pengantar. (Jakarta: Diadit Media, 2007). 